\title{
将来 危惧される作業関連疾患と光の予防“
}

\section{青木和夫**}

\section{1. 職業と健康障害}

人間が職業に就くことによって様々な健康問題が生 じてきた，従来，このような健康障害は職業病とよば れ，その職業に就くことによって特異的に生ずるもの であった。その原因の多くは作業環境中の有害物質や 物理的なエネルギーの被曝によるものであり，作業の 場の物理・化学的環境の改善が健康障害を防ぐ最も重 要な方法であった。このような環境管理による職業病 の予防は着実に効果をあげてきた。

職業病にはこのほかに, 作業行動によって生ずる過 剰な負担によって発生するものがある. 重量物の運搬 によって生ずる腰痛, データエントリー作業などの高 密度の手指作業によって生ずる頸肩腕障害などがその 代表的な例である。近年ではVDT 作業による視機能 の低下などが問題とされてきた．このような作業行動 が原因で生ずる健康障害に対しては, 作業方法の改善, 作業量や時間の規制による負担の軽隇対策が予防に効 果的であり，このような作業管理は人間工学がおおい に活躍する場でもあった.

ところが最近の産業保健の分野では, 突然死あるい は過労死を代表とする循環器系疾患に話題が集まって いる. しかし, 循環器系の疾患はある特定の職業にの み生ずるものではなく, また, 職業に就いていない者 にも生ずるものである.したがって，このような疾患 を職業病とよぶことは適当でなくなった。しかし，休 みもとらずに働いた結果生じた突然死は, やはり労働 が原因であると考えざるをえないものであり, 労働上 の対策が必要である.このような場合には健康管理が 重要な役割を果たすことになる.

$*$ 平成 5 年 2 月 2 日受付

** 日本大学大学院 理工学研究科

Graduate School of Science \& Technology, Nihon Univ.

\section{2. 作業関連疾患}

循環器系疾患などによる突然死は, 高血圧や高脂血 症，動脈硬化などの基礎疾患がある場合に起こること が多いとされている．このような循環器系疾患のリス クの高い状態で休養をほとんどとらずに働いた場合, その負担が引金となって突然死や脳心事故が発生する 可能性が高くなると考えられている．しかしこの場合， 突然死の原因がすべて職業にあったとはいいがたい. 日常の食生活や運動不足, 喫煙などが循環器系疾患の リスクを高めてきた原因であり，過剩な作業負担は発 症の引金にすぎないとも考えられるからである.この ような発生のしかたをする疾患を作業関連疾患とよび, 従来の職業病とは異なる概念でとらえられてきている.

\section{3. ストレス関連疾患}

ストレスとは外部の刺激によって生体に生ずる適応 反応のことである。本来このような生理的な現象をさ して用いられた言葉であるが，一般にはこのような反 応を起こす外部刺激をストレスとよんでいる，さらに， この外部刺激も物理的・化学的なものよりは，むしろ 精神的なものが主にストレスとよばれるようになって きている.

このようにストレスという言葉が精神的な外部刺激 に主に用いられるようになったのは，社会生活におい て精神的な負担の加わることが多くなってきたからで あると考えられる。これは日常生活においてもそうで あるが，労働の場においても精神的な負担が大きくな っていることは明らかである。

ストレス関連疾患とは，精神的なストレスが発症や 疾病の進行に影響を与えていると考えられる疾患であ るが，その範囲はあいまいである．胃潰瘍は，セリエ のストレス学説の発表のときにすでにストレスが原因 で発症することがわかっていたが，現在では心疾患， 脳血管疾患などの循環器系疾患の大部分, そして癌も 
ストレスが関係しているとまでいわれている，しかし， その因果関係は明確ではなく，ストレスが原因である と断定することはできない。むしろこのような疾患に は原因とよびうるようなものはないのかもしれない. 労働生活を含めた個人の生活全体が原因となっている と考えるべきであろう。

\section{4. 今後 増加する疾患と炎の予防対策}

このように，なにやら原因の明確でない疾患の発生 予防が今後の健康管理対策の中心となっていくことは まちがいないであろう。しかし，原因がわからないか らといって何も対策をとらないということはできない. 今後, 増加するであろうと考えられる疾患は, 特定の 作業に関連しているというよりは，広く一般の人々に もみられるものとなるであろう。様々な個人の社会生 活の背景のなかで, 作業にようて疾患の発生リスクが さらに高まることを予防することが必要になるであろ う.ここでは，そのような疾患の例をいくつかあげて 対策を考えてみたい。

\section{（1）虚血性心疾患}

狭心症, 心筋梗塞は心筋を養う冠状動脈の狭窄によ って発生する，その原因の多くは冠状動脈の硬化によ るものであり, 高血圧や高コレステロール血症が動脈 硬化を促進する，そして，高血圧や高コレステロール 血症には肥満や運動不足, 動物性脂質の過剩摂取など が影響している。ささに，精神的ストレスも影響を与 えていると考えられている. 実際, 食生活の改善, 運 動量の増加によって肥満の解消をすることで, 症状が 改善されることがわかっている。一方, 精神的ストレ スについても様々な対処法が示されているが, まだそ の効果については明確な結論はでていない.

虚血性心疾患の発症は突然に起こることが多い。つ まり, 心筋の酸素要求量に対する血液の供給量が不足 した場合に発症する.したがって, 心筋の酸素要求量 を必要以上に高めないこと, 血液の供給量を減少させ ないことが, 発症の予防には必要である. 酸素要求量 を高めないためには，身体的・精神的作業の負荷の軽 減が考えられなければならない。

一方, 個人の生活に扔いても, 虚血性心疾患のリス クを少なくするような生活習慣を確保することによっ て, 血液の供給量を減少させないことが必要である. 虚血性心疾患の原因の第一は動脈硬化であり, これは 血中のコレステロール，特に LDL コレステロールが 高い場合に進行しやすい. 動物性の脂肪のとりすぎと 運動不足が血中のコレステロールを増加させることが わかっている.このような生活の結果として, 肥満,
特に体脂肪率の増加が生じてくるわけであり, 虚血性 心疾患の予防には肥満を解消することが最も効果的で あるといえよう。その場合に, ただ体重が減少すれば よいというのではなく, 動物性脂肪の制限, 緑黄色野 菜を多くとる, 体を動かすために交通機関を利用せず に歩く習慣をつける, 階段を昇るなどの日常の生活の パターンを再設計することによって, 自然に肥満が解 消していくということが理想的である. やせるのでは なく, 生活習慣の改善された結果として適切な体重に 到達するという考え方が必要である.

\section{(2) 腰痛, 肩こり}

現代人の多くは腰痛に悩まされている，また，肩こ りは日本ではごく普通にみられる現象であったが，外 国でも最近, 頸と肩の痛みとして注目されている. 外 傷性のものを除くと, 腰痛症の多くは重量物の取り扱 いによって生じてきた.つまり, 取り扱う物体の重量 が問題となってきたわけである. しかし, 最近の労働 形態では重量よりも取り扱う回数, つまり密度が影響 してきている. 比較的軽い物体でも, 休みなく繰り返 し取り扱うことによって腰痛が生じてくる.肩こりも 同様であり，上肢作業を高密度に行うことによって生 じてくる.さらに，同一姿勢の保持も腰痛や肩こりの 要因とされている.

腰痛, 肩こりの原因は生体の筋力, 筋持久力に対し て作業負荷が過大なために生ずると考えられる。そこ で負荷と筋力のバランスをとることが必要になってく る. 作業負荷は瞬間的な負荷の大きさよりは，むしろ 密度の設計が, これからは必要となってくるであろう. また, 運動不足による筋力, 筋持久力の低下を防ぐた めのトレーニングもあわせて必要になってくると考え られる。

ある職業に必要な体力は, 職業に就きながら確保し ていくということが理想であるが, 作業の密度が問題 となるような動作では, 必要な筋力を作業のなかで得 ることは困難である。したがって, 作業に必要な体力 を作業以外のところで養っていく必要がある。これは 野球のシーズンオフのトレーニングの必要性と同じで ある. 彼らがトレーニングをわざわざ行うのは，ゲー ムをしているだけではゲームを行うのに必要な体力が 衰えてしまうからである.職業も含めた日常の生活が 体力を衰えさせ，作業に必要な体力を得られないとす れば，体力を維持するための特別なトレーニングが必 要になってくる．このようなトレーニングを労働の場 や時間に組み込むべきなのか，あるいは個人の責任で 日常生活のなかに組み入れるべきかは議論の余地があ るだろう。しかし，人間工学的な作業設計の考えのな かに，このようなトレーニングの必要性が取り入れら 
れる必要があると考える.

（3）うつ病，アルコール依存

いわゆる中年期の精神的問題は，うつ病やアルコー ル依存として現れてくることがある．職場における人 間関係，仕事での満足が得られない，いわゆる燃えつ き症候群など，職業の種類に関係のある場合もない場 合も含めて, 精神的なストレスが影響していると考え られている．職場の組織の設計が対策として考えられ なければならないが，職業上ばかりでなく，その個人 の人生全体の価值観に関わってくることも多い. した がって, 単純に職場だけの対策では対応しきれないこ ともある。

現在ではうつ病は治療可能であり，アルコール依存 も治療が進んできている，職場の対策としては，この ような症状を早期に発見し，精神的な疾患も，心疾患， 肝疾患といったような身体的疾患と同じょうに，誰で もかかりうるものであり，また治療によって治癒する ことを理解したうえで，治療に協力できる体制を整え ておくことが必要であると考える。

うつ病の症状は，本人にとっては意欲がなくなり， 物事に感動しなくなったり，たいへんにつらいもので あるが，なかなか周囲の人間が気づかないことが多い。 外からみた症状は，なんとなく元気がない，動作が鈍 い，不眠を訴える，食欲がなくてやせてくる，欠勤す るなどである．誰でもこのようなことはよくあるわけ であるが，たいていはそう長くは続かないものである。 もし，いつもこのような状態が続いているとしたら， 要注意と考えるべきであろう.

アルコール依存はアルコールがないといられないと いう状態であるが，職場でアルコールを飲むことはで きないので，なかなか気がつかないことも多い. しか し, 二日酔いが続いているとか, 遅刻, 欠勤が増えて いるというような場合は要注意である.また，ひとり で飲むことが多くなるため，みんなと飲むのを断った
りすることが多くなる，さらに，飲み始めると必ず完 全に酔うまで飲み続けてしまうというような場合も多 い.

このような場合に，周囲の者が本人に忠告してもあ まり効果がないことが多い. 本人の信頼できる人がい ればその人に相談し，専門家のカウンセリングの機会 を設けることが必要である。

\section{5. 職場の快適性と健康}

従来, 労働は生産の場, 家庭は休養の場であり, 明 確な区別があった。したがって, 労働による健康障害 を防ぐのは職場の責任であり, 個人の生活の健康障害 を防ぐのは家庭や地域の責任であった．しかし，個人 の生活上の健康問題が労働の場で発生したり, 逆に労 働の場の問題が個人の生活の健康問題となるようにな ってくると，このような労働と家庭の生活を分離して 考えることはあまり意味のないことになってくる.

これから増加するであろうと考えられる作業に関連 した疾患は，労働や作業のみによって発生するのでは なく, 個人の生活全体と関わってくるものである.し たがって，職場における対策だけでは不十分であり， 生活全体の設計と関わらざるをえなくなるであろう。 つまり，労働も個人の生活も一緒にした生活設計を行 うという発想の転換が必要になるのではないだろうか。

このことは，個人が快適に生活をおくることが，家 庭内で個人の努力によってのみ行われるのではなく， 職場においても快適な職業生活がおくれるようになら なければならないことを意味している．このように考 えてくると, 将来的には職業病はもとより作業関連疾 患という概念すらなくなるのかもしれない. 職業生活 も含めたライフスタイル全体と健康障害の関係が議論 されるようになってくるであろう. 